\title{
Peanut Crisp: A Protein-Rich SnACK
}

\author{
Annalene Grace E. Co*, \\ College of Teacher Education \\ Quirino State University, Maddela, Quirino, 3404 \\ Philippines \\ annalenegrace.co@qsu.edu.ph \\ Orcid ID: https://orcid.org/0000-0002-8042-7877 \\ Roselle M. Soriano \\ College of Arts and Sciences \\ Quirino State University, Cabarroguis, Quirino, 3402 \\ Philippines \\ sorianorosellel@gmail.com \\ Orcid ID: https://orcid.org/0000-0001-5190-4374
}

*Corresponding Author email: annalenegrace.co@qsu.edu.ph

Submission: 14 March 2021

Revised: 20 May 2021

Accepted: 02 June 2021

Peer-review under responsibility of 5th ASIA International Multidisciplinary Conference 2027 (Online)

Scientific Committee

http://connectingasia.org/scientific-committee/

(c) 2021 Published by Readers Insight Publisher,

Office \# 6, First Floor, A \& K Plaza, Near D Watson, F-10 Markaz, Islamabad. Pakistan,

editor@readersinsight.net

This is an open access article under the CC BY license (http://creativecommons.org/licenses/by/4.0/). 


\section{A B S T R A C T}

Peanut processed products sold in the local market are still limited but the potential is great. There is a need therefore to explore more diversified peanut products that are acceptable, nutritious, and within the buying capacity of the general consumers. This study aimed to produce crisp; a very popular snack food utilizing rice and peanut at various levels applying some appropriate technologies. The products were analyzed and evaluated to determine their sensory qualities, nutritive value, and profitability. The treatments of the study were different proportions of rice and peanut. Replication was done three times and Completely Randomized Design (CRD) was used. The crisp products were rated and results showed that these had good sensory qualities. Peanut significantly improved the taste and crispiness acceptability as well as the protein quality. Based on cost and return analysis, the commercial processing of the products either in a household or small scale operation indicates good economic profitability.

Keywords: Peanut, Crisp, Protein-Rich Snack, Acceptability, Profitability

\section{R E S E A R C H H I G H L I G H T S}

1. Peanuts have mostly been used in the food industry for direct use as a snack food. Its sensory properties and value, on the other hand, make it a common raw material for food product production (1).

2. Peanuts are an excellent enriching ingredient because of their high protein content and taste. It is recommended that peanut flour and isolates be developed and used to complement, fortify, and enhance the taste and quality of foods (2).

3. Peanut processing can be profitable if proper cultural management and an effective scheme are used (3).

\section{Research Objectives}

The current research study was initiated by the researchers with the aim of extending the uses of peanut and providing variety to customers.

The study aimed to develop/improve processing technologies of new peanut products. Specifically, it seeks answers to the following questions: 1) What is the level of acceptability of the peanut processed products with regards to its sensory properties; 2) What is the nutritive quality of the processed product; and 3) What is the economic profitability of commercializing the peanut products.

\section{Methodology}

The study was conducted at Quirino State University, a university in Southern Cagayan Valley, Philippines. Preliminary trials were performed to come out with the optimum formulations and viable as well as effective and efficient processing technologies in producing quality peanut crisp. The identified appropriate processing technology was 
composed of three basic steps, namely: preparation of rice flour, preparation of peanut sapal and preparation of crisp.

Treatments of the study were the different proportions of rice and peanut, namely: $77-1: 0$ (100\% rice and 0\% peanut), T2 - 3:1 (75\% rice and 25\% peanut), and T3 - 1:1 (50\% rice and 50\% peanut). Replication was done three times and Completely Randomized Design (CRD) was used in this study.

The products were evaluated for color, odor, tastes, crispiness and general acceptability. Samples were presented to consumer-type panelists and score cards were provided for proper evaluation (4).

The nutritive quality of the product particularly the protein content was analyzed using standard analytical procedure. This was performed at the Nutrition Laboratory of the department of Science and Technology (DOST) of Region 02.

Calculations were done on the processing cost, return on investment and payback period.

\section{Results}

The crisp products were all accepted with a mean rating ranging from "Like Moderately" to "Like Very Much". Statistically, there were no significant differences among the samples in terms of color, odor, and general acceptability. However, higher acceptability was noted on the taste and crispiness of peanut products. Thus results confirm the unique and appealing flavour offered by peanut as compared to the somewhat beany flavour of soy beans (1).

Chemical analysis of the crisp products showed that T3 had the highest mean of 9.21\% crude protein, followed by $\mathrm{T} 2$ with $7.27 \%$ and the least was $T 7$ with $5.28 \%$. Highly significant variations were observed among treatment means as far as crude protein is concerned. This confirms the reports that cereal products could be fortified with the addition of legumes like peanut (5).

The economic returns of the different treatments were computed accordingly based on the cost of processing and total sales from the different treatments. It came out that

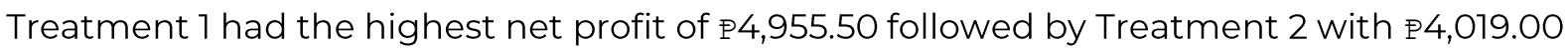
and Treatment 3 with $\mathrm{Pl}$, 963.50. Admittedly, the net income of the different treatments with peanut was lower than that of the treatment with rice alone (5). This might be due to the equal-cost of the finished crisp products in all the treatments without giving a premium to their nutritive value and palatability. However, the technology will certainly lead to the development of a product like a peanut crisp which could ultimately be very profitable due to its wholesomeness and nutritive value (3).

\section{Findings}

Peanut crisp is crunchy or crispy protein-rich snack. It has an appealing cereal and peanut taste enhanced further by the addition of flavoring. It is nutritious fortified with macro and micronutrients. The processing technology of making peanut crisp is simple and easy to follow particularly for household and small-scale enterprises. It was assessed as 
economically feasible in the commercialization of peanut crisp. Due to all of the abovementioned factors, it is obvious that there is a lot of room for peanut products to be commercialized, and consumer dynamics seem to be very positive.

\section{Acknowledgement}

The researchers wish to acknowledge with gratefulness the administration of Quirino State University for permitting the researchers to conduct the study in the university; to the DOST Region 02 for their assistance in the laboratory testing; and to the faculty and students of the University for their cooperation, support, and assistance.

\section{References}

1. Garcia, V. V. An overview of peanut in the Philippines. Proc. of the 15th World Congress of Food Science \& Technology: Singapore. 2017

2. Escueta, E. Utilization of peanut as food in the Philippines. Proc. 1st National Peanut Consultation and Peanut-CRSP Review Book Series No. 39. 2015: Pp. 81-86.

3. PCARRD-DOST-CVARRD. Peanut production Technology. CVARRD Farm Primer No. O2/2014 Los Banos, Laguna, Philippines. 2014

4. Palomar, L. S, Lustre, A. O. \& Resurrection, A. V. Improvement and optimization of peanut products of company collaborators in Luzon, Philippines. Paper presented during the Institute of Food Technologists (IFT) Annual Meeting, Atlanta, Georgia, USA. 2015.

5. Bouchenak, M. Nutritional quality of legumes. 2013: Retrieved on September 3, 2017 from https://www.ncbi.nlm.nlh.gov.pubmed.

6. Recide, R. S. Cost and returns of peanut production. Bureau of Agricultural Statistics. Department of Agriculture, Diliman, Quezon City. 2015.

\section{Author's Biography}

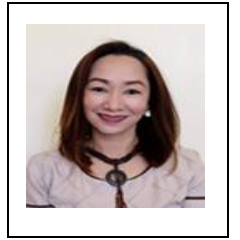

Annalene Grace E. Co received her master's degree in Science Education from the University of La Salette, Inc., Philippines in 2012. Then she pursued her Ph.D. study in Science Education in 2014 and Educational Management in 2018 in the same University. She has 5 years of experience in teaching science courses and has done researches on Applied Sciences. Currently, she is working as Assistant Professor and the Program Chairperson of the Bachelor of Secondary Education in Quirino State University, Maddela Campus, Philippines. Her research interests focus on product development in Science and Technology.

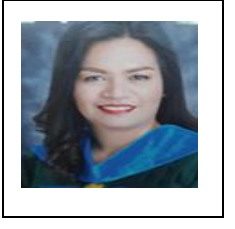

Roselle M. Soriano, Assistant Professor and Program Chairperson of Bachelor of Arts in English language Studies. She finished her Doctor of Philosophy in Rhetoric and Linguistics at St. Paul University, Philippines. Her areas of interest are Higher education and Social Sciences. She presents at international conferences and has supervised many students in their research endeavors. 